\title{
Giveren, gaven, modtageren og gensidigheden
}

\section{Om gavens økonomi i nogle af Kierkegaards opbyggelige taler}

\author{
Lektor, ph.d. \\ Pia Søltoft
}

\begin{abstract}
In this article we will read Kierkegaard in continuation of the un-going debate about the economy of the gift. I will argue that $\mathrm{Ki}$ erkegaard's notion of love as a three-part-relation in many ways exceeds the insights in the economy of the gift that Marcel Mauss gained hold of in his anthropologic studies in 1925. Insights which have led to an un-going debate about the "pureness" of the gift between philosophers like Jacques Derrida, Emmanuel Lévinas and Jean-Luc Marion and in recent theological studies as the ones by Bo Holm og Niels Henrik Gregersen. In what follows I will put attention to how Kierkegaard in his upbuilding discourses and in Works of Love describes love as a special mutual relation between the lover (the giver) the beloved (the receiver) and love itself (the gift). Hereby I wish to show that Kierkegaard's notion of love contains a deliberate contribution to the recent debate of the economy of the gift.
\end{abstract}

Key-words: Economy of the Gift - Mutuality - Reciprocity - Love Neighbour - Generosity - Marcel Mauss - Søren Kierkegaard

Tematiseringen af gavens økonomi er et "hot" emne inden for både teologi ${ }^{1}$ og filosofi. ${ }^{2}$ Men denne tematisering er ikke noget nyt fæ-

1. Udgivelserne The Gift of Grace, red. Niels Henrik Gregersen, Bo Holm m.fl., (Minneapolis: Fortress Press 2005) samt Word - Gift - Being, red. Bo Kristian Holm og Peter Widmann, (Tübingen: Mohr Siebeck 2009), der alle er blevet til på dansk initiativ med i samarbejde med internationale kræfter og forlag, vidner netop om den store interesse for gavens økonomi i teologisk regi. Det er en interesse, der på en frugtbar måde udfordrer den traditionelle lutherske opfattelse af Guds nåde som en ren gave og næstekærligheden som en ensidig fordring. I det følgende ønsker jeg at tage denne udfordring op og i lyset heraf forslå en tolkning af Kierkegaards syn på kærligheden som en gave, der ligeledes lægger op til en fokusering på gensidighedsaspektet.

2. Det er især inden for den etiske og fænomenologiske tradition, at gavetematikken er dukket op indenfor de seneste 20 år. Ser man bort fra John Milbanks prægning af diskussionen er det især navne som Emmanuel Lévinas, Jean-Luc Marion, Jacques Derrida og John D. Caputo, der har præget debatten. Referencer til de enkelte tekster gives i det følgende, hvor de anvendes. 
nomen. Som bekendt besluttede den franske antropolog og sociolog Marcel Mauss (1872-1950) sig allerede i 1925 for en grundig undersøgelse af gavebegrebet. ${ }^{3}$ På baggrund af en analyse af den ceremonielle udveksling af gaver i to primitive samfund i Polynesien og Nordamerika, nåede han frem til, at der i gavegivningen er indbygget et sindrigt system af gensidighed, der bygger på moralske dyder som respekt og anerkendelse, hvilket kommer til udtryk gennem et uudtalt krav om en gengave, som dog ikke må forveksles med gengældelse i strikte forstand. Der er nemlig hverken tale om, at modtageren skal give det samme eller noget tilsvarende igen, idet begge dele ville forudsætte at gaven i egentlig forstand kunne måles. Der er omvendt tale $\mathrm{om}$, at modtageren skal modtage gaven på en sådan måde, at giveren føler sig anerkendt som giver, ikke fordi han eller hun får det samme eller noget tilsvarende igen, men fordi der i gengaven ligger en anerkendelse af selve forholdet mellem giver og modtager. Herved opstår en særegen gaveøkonomi og det er denne økonomi, vi i det følgende skal se tematiseret i Søren Kierkegaards (1813-1855) syn på, hvad det vil sige at elske og blive elsket.

Ifølge Mauss afspejler gavegivningens økonomi den oprindelige, i.e. den førkapitalistiske, relation mellem mennesker. Gavens økonomi er tilstedeværende i primitive samfund og i den vestlige samfundsopbygning forud for den kapitalistiske markedsøkonomi. Med kapitalismen indføres et bytteobjekt, penge, hvorved der kiler sig en afstand ind mellem giver og modtager, idet gaven nu kan repræsenteres ved noget andet af tilsvarende værdi. Hermed ophæves gavens særegne $ø$ konomi og erstattes af et regnskabsforhold. Den personlige og gensidige respekt mellem giver og modtager bortfalder, når gaven kan erstattes med noget andet, der har en neutral, men tilsvarende bytteværdi. Så er det ikke længere forholdet mellem giver og modtager, der er i centrum, men derimod gaven som en selvstændig værdifuld genstand.

I det følgende er det dette særegne forhold mellem giver og modtager, der skal interessere os, idet det kan siges at afspejle den forunderlige form for gensidighed, som Kierkegaard peger på i forbindelse med kærligheden som en gave. Der er således ikke tale om, at jeg i udgangspunktet tager anstød af det gensidighedsforhold, som Mauss afdækkede i sine sociologiske og antropologiske studier og som har ført til en mistænkeliggørelse af den "rene" gaves mulighed hos blandt

3. Før Mauss beskæftiger både Ralph Waldo Emerson (1803-1882) og Friedrich Nietzsche (1844-1900) sig med gavegivningstanken, hvilket Niels Henrik Gregersen så oplysende redegør for i "Generøsitetens teologi”, DTT 71 (2008), 77-99. En artikel der på fornemste vis giver et overblik over gavetankens historie. 
andet Jacques Derrida (1930-2004), men derimod om et forsøg på at tanke en saregen form af gensidigheden med i kærlighedsforholdet. ${ }^{4}$

\section{Gavens oprindelige økonomi}

Den oprindelige gaveøkonomi, sådan som Mauss fremanalyserer den, lever af en overensstemmelse mellem giver og modtager, der netop ikke hviler på gavens kommercielle værdi, hvor penge kan benyttes som mellemled, og hvor giver og modtager ikke er socialt afhængige af hinanden og ikke står $\mathrm{i}$ et personligt forhold til hinanden. Den oprindelige gaveøkonomi bygger omvendt på en gensidig respekt for nogle fælles værdinormer mellem giver og modtager, hvilket afspejler sig i gaven og gengavens art. Udvekslingen af gaver er således med til at opretholde de sociale relationer $i$ en given befolkningsgruppe.

Mauss redegør for denne gaveøkonomi i sin lille bog Essai sur le Don, ${ }^{5}$ hvor han netop slår til lyd for, at forpligtelsen til at give, modtage og gengive gaver etablerer et socialt, moralsk bånd mellem giver og modtager, hvor gensidigheden er i centrum. Giveren overfører ved sin gave anerkendelse og ære til modtageren, der derfor stilles i en art positivt afhængighedsforhold. Modtageren skal for sin del vide at modtage gaven, da en afvisning ville være en afvisning af giverens respekt og ære og derfor ikke blot en afvisning af gaven, men også af giveren. Og modtageren skal tillige gengælde gaven, netop fordi $f_{x-}$ nomener som ære og respekt, ganske som anerkendelse og kærlighed, lever af en gensidighed. Gengældelsen kan således ikke gøres op i en bytteværdi, som for eksempel penge, men må med nødvendighed bygge på en gengivelse af respekt, anerkendelse eller kærlighed fra modtagerens side.

Mauss antropologiske og sociologiske studier har som nævnt virket inspirerende både indenfor filosofi og teologi i dag. I særdeleshed har Jacques Derrida tematiseret gavegivningens velsignelser og forbandelser og i The Gift of Death udviklet en teori om gavens økonomi i Kierkegaards pseudonyme værk Frygt og Bæven. ${ }^{6}$ Også Emmanuel Lévinas (1906-1995) og Jean-Luc Marion (1946-) ${ }^{8}$ har videreudvik-

4. Jacques Derrida, "Given Time 1", Counterfeit Money Volume 1 (Chicago \& London: University of Chicago Press 1992), 13.

5. Marcel Mauss, Essai sur le Don (Paris: Presses Universitaires de France 1950).

6. Jacques Derrida, The Gift of Death (Chicago/London: The University of Chicago Press (1992)1995) 53-81.

7. Emmanuel Lévinas, Entre nous. Essais sur le penser-à-l’autre (Paris: Grasset 1991). 8. "'On the Gift. A discussion between Jacques Derrida and Jean-Luc Marion", God, the Gift and Postmodernism, red. John D. Caputo \& Michael J. (Bloomington: Scanlon 1999). 
let gavemotivet i deres fænomenologiske analyser af forholdet til medmennesket, deres tematisering af "den Andens" betydning for subjektiviteten og deres udvikling af gensidighedens rolle og problem.

I et protestantisk teologisk perspektiv er det naturligvis netop gensidighedsaspektet i gaveøkonomien, der tematiseres. Der er en lang, luthersk tradition for at opfatte retfærdiggørelsen som en ren gave fra Gud til mennesket. Sidstnævnte har kun til opgave at modtage den skænkede gave i tro. Og da troen også er skænket, idet den kommer af det, der høres, synes alt vægt at ligge på gaven og giveren, mens modtageren ikke levnes megen opmærksomhed og gensidigheden ofte afvises som gerningsretfærdighed.

Bo Holm sætter dog spørgsmålstegn ved denne negligering af modtageren og dermed af gensidighedsaspektet i protestantisk teologi i sin oplysende artikel "Luther's Theology of the Gift", hvor han netop argumenterer for en form for retfærdiggørelsesøkonomi (Gregersen, Holm, Peters \& Widmann 2005, 85). Det er i en vis forstand samme ærinde Niels Henrik Gregersen er ude i, når han slår til lyd for tanken om en "radikal generøsitet", der dels indebærer at giveren kan tænkes at give uden at forvente at få gengæld, dels åbner relationen mellem giver og modtager på en sådan måde, at der ikke blot bliver tale om at den ene gengælder den andens gave, men om at den enes gave kan medføre en given fra den anden til den tredje og så fremdeles.?

I det følgende vil vi læse Kierkegaard i forlængelse af disse nye indsigter i gavens økonomi og således stille skarpt på, hvorledes man i en kierkegaardsk optik kan se gavens oprindelige økonomi genetableret i synet på kærlighed. Udgangspunktet er, at "Kjerlighed søger ikke sit Eget; thi den giver helst saaledes, at Gaven seer ud som var den Modtagerens Eiendom" (SKS 9, 272). Vi vil således argumentere for, at Kierkegaard i flere af sine opbyggelige taler, og i særdeleshed i Kjerlighedens Gjerninger, som vi i nærværende sammenhæng vil opfatte som en samling opbyggelige taler, evner at beskrive kærligheden som et fænomen, der ytrer sig gennem et særegent gensidighedsforhold mellem giveren (den der elsker) og modtageren (den der elskes) og selve gaven (kærligheden). Et forhold der på mange måder forgriber de indsigter, som Mauss på baggrund af sine sociologiske og antropologiske feltstudier i 1925 analyserede sig frem til. Men i måden, hvorpå

9. Niels Henrik Gregersen: "Radical Generosity and the Flow of Grace" i: Holm \& Widmann (2009), 117-144 (139): "A theology of generosity can thus clarify why the discourse of God's grace must avoid being caught in a vicious circle endlessly shuttling from guilt to forgiveness, forgiveness and guilt, back and forth from the deficiency of sin to the equilibrium of forgiveness. Quite the contrary: Divine generosity is a passing on of generosity, a releasing of generosity from God to humanity, and from human beings to their neighbours - in a fundamental reliance on the viscosity of the social field". 
Kierkegaard fremstiller kærligheden som et trepartsforhold, tillades der en særegen form for gensidighed i rummet mellem elskeren og den elskede. Det følgende falder i otte afsnit, der hver især tematiserer den firdelte overskrift. Vi skal således se på, hvorledes Kierkegaard anskuer giveren, gaven, modtageren og gensidigheden, når det drejer sig om en bestemmelse af kærligheden.

\section{Trepartsforholdet}

Forskellen på et sandt gensidighedsforhold og et regnskabsforhold er Kierkegaard om nogen opmærksom på. Hans udgangspunkt er, at et sandt kærlighedsforhold bygger på en særegen økonomi i forholdet mellem den elskende og den elskede og kærligheden. Kierkegaard hylder således tanken om kærlighed som en trepartsrelation og siger om bogen Kjerlighedens Gjerninger fra 1847:

Men i dette lille Skrift handle vi bestandigt kun om Kjerlighedens Gjerninger, og derfor ikke om Guds Kjerlighed, men om menneskelig Kjerlighed. Naturligviis, intet Menneske er Kjerlighed; han er, hvis han er i Kjerlighed, en Kjerlig. Og dog er Kjerlighed overalt tilstede, hvor der er en Kjerlig. Man skulde troe, og man mener vel ogsaa oftest, at Kjerlighed mellem Menneske og Menneske er et Forhold mellem To. Dette er ogsaa sandt, men usandt, forsaavidt dette Forhold tillige er et Forhold mellem Tre. Først er der den Kjerlige; dernæst Den eller De, som ere Gjenstanden; men for det Tredie er ogsaa Kjerligheden selv med tilstede. ${ }^{10}$

I forlængelse af det netop citerede er det nok rigtigst her indledende at understrege, at Kjerlighedens Gjerninger ikke udelukkende handler om næstekærlighed. Kierkegaards grundforudsætning er, at der er én kærlighed. Denne ene kærlighed er religiøst funderet al den stund Kierkegaard med metaforisk målrettethed konsekvent kan tale om, at det er Gud, der har nedlagt kærligheden i et menneske, ${ }^{11}$ og at det derfor er Gud, der til enhver tid bestemmer, hvad kærlighed er. Men til grundforudsætningen om denne ene kærlighed, der har guddommeligt ophav, knytter der sig endvidere en lige så fundamental tanke om, at den kærlighed ethvert menneske har fået skænket af sin skaber, aldrig er uvirksom. Kierkegaard kan direkte understrege, at kærligheden ikke er en for-sig-værende egenskab ved det menneskelige, men netop en egenskab, i hvilken det ene menneske er til for det andet.

10. Søren Kierkegaards Skrifter (København: Gad 1997-2012), bd. 9, 299f (herefter citeret som SKS, efterfulgt af bind og sidetal).

11. "Det er Gud, der har nedlagt Kjerligheden i Mennesket, og det er Gud, som skal bestemme, hvad der i ethvert Tilfælde er Kjerlighed" (SKS 9, 129). 
For Kierkegaard er kærlighed og handling derfor uløseligt forbundne og det er denne intime forbindelse mellem kærligheden og dens gerninger, der ikke bare har givet navn til bogen fra 1847, men tillige tillader os at stille skarpt på forholdet mellem den kærlige, der elsker en anden og dermed er giveren af kærlighed i en bestemt relation, selve gaven, som er den kærlighed, der gives, og modtageren, den elskede, der som elsket modtager den andens kærlighed og hermed sin egen elskværdighed.

Som det vil blive klart i det følgende argumenterer Kierkegaard for, at dette forhold hviler på en særegen gensidighed, der i mangt og meget minder om den oprindelige gaveøkonomi, som Mauss beskriver i sine sociologiske og antropologiske studier. Hos Kierkegaard er der således også tale om en form for økonomi og dermed gensidighed, når det drejer sin om gaven kærlighed. Denne påstand skal vi se nærmere på i det følgende, ikke kun ved at inddrage Kjerligehedens Gjerninger, men tillige med udblik til andre af Kierkegaards opbyggelige taler.

\section{Giveren er i uendelig gæld}

I talen 'Vor Pligt at blive i Kjerlighedens Gjeld til hverandre' fra Kjerlighedens Gjerninger præsenteres giverens, den elskendes, rolle (SKS 9, 175-203).

I denne tale kommer Kierkegaard meget hurtigt frem til, at den mest rammende beskrivelse af kærligheden i et menneske, er en beskrivelse af fornemmelse af at stå i et uendeligt galdsforhold. Men i samme åndedrag fastslår han, at beskrivelsen af kærligheden som en gæld, ikke er en beskrivelse af modtagerens, den elskedes, forhold til den der elsker, men omvendt en beskrivelse af giverens, den der elskers, forhold til den elskede. Kierkegaard vender således gældsforholdet på hovedet når det gælder kærligheden, idet han argumenterer for, at det at elske et andet menneske kan beskrives som en fornemmelse af, ja, et stærkt ønske om, at stå i en uendelig gæld til den elskede.

Og det er netop en afgørende pointe, at den gæld den elskende står i til den elskede er uendelig. Den elskende kommer aldrig ud af gælden og vil det heller ikke. Der er med andre ord tale om et gældsforhold, der aldrig ophører, men samtidig også om et gældsforhold, der aldrig bliver et gengaldelsesforhold:

Dog rigtigst beskriver man maaskee Kjerligheden som en uendelig Gjeld: at et Menneske, naar han gribes af Kjerlighed, fornemmer dette at være som at være i en uendelig Gjeld. [...] Den, som elsker, han er i Gjeld; idet han fornemmer sig greben af Kjerligheden, fornemmer han dette som at være i en uendelig Gjeld. Vidunderligt! At give et Menneske sin Kjerlig- 
hed er jo, som sagt, det Høieste et Menneske kan give - og dog, just idet han giver sin Kjerlighed, og just ved at give den kommer han i en uendelig Gjeld. Derfor kan man sige, at dette er Kjerlighedens Eiendommelige: at den Elskende ved at give, uendeligt, kommer-i uendelig Gjeld (SKS 9, 176).

At elske er at forblive i en uendelig gæld til den elskede. Hvad vil du nu sige? Ja, det vil netop sige ikke at opfatte kærligheden som et bytteobjekt, som den ene giver den anden for at få det samme igen. Naturligvis er kærlighed noget, den elskende, giveren, som oftest giver $i$ håb om at få kærlighed igen af den elskede, modtageren. Når det drejer sig om elskov og venskab er håbet om gensidighed udtalt, $\mathrm{i}$ forældrekærligheden som ofte uudtalt med stadig nærværende ifølge Kierkegaard, mens næstekærligheden netop synes bestemt ved sin mangel på gensidighed. Og alligevel er det ikke helt sådan.

Naturligvis kan den, der elsker næsten ikke kreve gengæld. Men det kan den, der elsker sin kæreste, kone, ven eller barn nu heller ikke. Men hvor de fire sidstnævnte forhold er kendetegnet ved en form for genkærlighed, så er næstekærligheden netop kendetegnet ved et fraver af genkærlighed. Dog er det vigtigt at pointere, at fravær af genkarlighed ikke er det samme som fravær af gensidighed. For selv om næstekærligheden ikke bestemmes gennem næstens genkærlighed, så er den gensidig al den stund, at når den ene giver sin kærlighed til den anden, så finder der en ændring af denne andens selvforståelse sted. Han eller hun bliver grundet kærlighedens gave til den elskverdige. Denne ændring medfører ikke, at kærligheden nødvendigvis returneres som gengave, men at den gives videre i forholdet til andre gennem den elskedes ændrede selvforståelse som elskværdig. Giverens generøsitet gives videre til modtageren.

Giveren kan således ikke kræve modtagerens genkærlighed til gengæld eller i bytte. Den der elskes, modtageren, står ikke i gæld til den der elsker. Det er giveren, der står i gæld, i uendelig gæld til modtageren, fordi det at elske betyder uendeligt at ville skænke sin kærlighed til den elskede, uden krav om gengældelse. Hvis det ikke var således, siger Kierkegaard, så ville ethvert kærlighedsforhold være at forstå som et regnskabsforhold:

I Almindelighed taler man om, at Den, der bliver elsket, ved at blive elsket kommer i Gjeld. Vi tale saaledes om, at Børn ere i en Kjerlighedens Gjeld til Forældrene, fordi disse have elsket dem først, saa at Børnenes Kjerlighed kun er et Afdrag paa Gjelden, eller en Gjengjeld. Og dette er ogsaa sandt. Men dog er denne Tale altfor meget mindende om et virkeligt Regnskabs-Forhold: der er en Gjeld andraget, og den skal afbetales; det er Kjerlighed, der er viist os, og det skal afbetales med Kjerlighed. Derom tale vi nu ikke, om, at man ved at modtage kommer i Gjeld (SKS 9, 176). 
Tanken er således, at der ligger en opgave til grund for kærlighedsforholdet. Opgaven er netop at sikre, at den særegne gaveøkonomi opretholdes, således at den elskende ikke elsker for at få en tilsvarende kærlighed i bytte for sin kærlighedsgave, men alligevel håber på genkærlighed og således initierer en gensidighed, der dog ikke kan kræves. Opgaven ligger i udgangspunktet på giverens side. Det er giverens, den elskendes, opgave at skænke sin kærlighed, gaven, på en sådan måde, at det ikke er modtageren, der kommer i gæld, men derimod giveren, der vedblivende står $\mathrm{i}$ et gældsforhold til modtageren. At dette gældsforhold på giverens side er uendeligt vil sige, at den elskende aldrig kommer ud af gælden og heller ikke ønsker det. Kierkegaard understreger netop at $i$ andre gældsforhold, det være sig "Penge-Gjeld, Æres-Gjeld, Løfte-Gjeld" (SKS 9, 177), er opgaven at komme ud af gældsforholdet så hurtigt som muligt. Men sådan er det ikke men den uendelige gæld på giverens side i kærlighedsforholdet:

Den Elskende ønsker altsaa for sin egen Skyld at blive i Gjelden; han $ø$ nsker ikke Fritagelse for nogen Opoffrelse, langtfra. Villig, ubeskriveligt villig, som Kjerlighedens Tilskyndelse er, vil han gjøre Alt, og frygter kun Eet, at han saaledes kunde gjøre Alt, at han kom ud af Gjelden. Dette er, ret forstaaet, Frygten; Ønsket er, at blive i Gjelden, men er tillige Pligten, Opgaven. Hvis Kjerligheden i os Mennesker ikke er saa fuldkommen, at dette Ønske er vort Ønske, saa skal Pligten hjælpe os til at forblive i Gjelden. |Naar det er Pligt at forblive i Kjerlighedens Gjeld til hverandre, da maa der tidligt og sildigt eller evigt vaages over, at Kjerligheden aldrig kommer til at dvale ved sig selv, eller til at sammenligne sig med Kjerligheden i andre Mennesker, eller til at sammenligne sig med sine Gjerninger, som den har udfort (SKS 9, 178).

At gensidighedsaspektet ligger implicit i opfattelsen af kærligheden som en gave, den elskende, giveren, skænker den elskede, skyldes kærlighedens opbyggelige karakter.

\section{Kærlighedens opbyggelighed}

Det er netop kærlighedens opbyggelighed, der gør den til en særegen gave. En gave, der både gives og modtages på en afgørende anderledes måde end $\mathrm{fx}$ en pengegave eller en gave, der kan gøres op i penge. Kierkegaard understreger netop, at det er en sarlig egenskab ved kærligheden, at den er opbyggelig. Han siger direkte, at det at være opbyggelig udelukkende er kendetegnende for kærligheden. ${ }^{12}$ Men hvad

12. "Dog er det i Sandhed saa, at det at opbygge er udelukkende eiendommeligt for Kjerlighed; men paa den anden Side, denne Egenskab opbyggelig har igjen den 
er så det opbyggelige ved kærligheden. Ja, det er netop dens evne til at fremelske kærligheden i det andet menneske, ved at forudsætte at kærligheden allerede er til stede i dette andet menneske.

Men hvad betyder det egentlig at opbygge? Kierkegaard går meget direkte til værks, når han skal forklare, hvori kærlighedens opbyggelighed og dermed dens overskudsaspekt består. Han tager udgangspunkt i den bygningsmetafor, der er indeholdt i selve udtrykket og siger, at det at opbygge er, at føre noget op i højden fra grunden af (jf. $S K S$ 9, 214ff). I overført betydning er det at opbygge derfor, at føre den kærlighed, der ligger $i$ Grunden i ethvert menneske op i højden; at elske det frem, der allerede på et helt fundamentalt plan er til stede i det andet menneske (jf. SKS 9, 213f.). Herefter giver han en beskrivelse af, hvorledes kærligheden opbygger:

Naar vi saaledes see et eenligt Menneske ved priisværdig Tarvelighed sparsomt at komme ud af det med Lidet, saa ære og prise vi ham, vi glædes, vi befæstes i det Gode ved dette Syn, men vi sige egentligen ikke, at det er et opbyggeligt Syn. Naar vi derimod see, hvorledes en Husmoder, som har Mange at sørge for, ved Tarvelighed og viis Sparsommelighed kjerligt veed at lægge Velsignelse i det Lidet, saa der dog bliver nok til Alle: da sige vi, at det er et opbyggeligt Syn. Det Opbyggelige ligger i, at vi paa samme Tid, som vi see Tarveligheden og Sparsommeligheden, hvilke vi ære, see Husmoderens kjerlige Omsorg. ${ }^{13}$

Eiendommelighed, at den kan hengive sig i Alt, være med i Alt - just lige som Kjerlighed" (SKS 9, 215).

13. Citatet fortsætter på følgende vis: "Derimod sige vi, at det er et lidet opbyggeligt, et uhyggeligt Syn, at see Den, som paa en Maade hungrer i Overflod, og som dog slet Intet har tilovers for Andre. Vi sige det er et rystende Syn, vi væmmes ved hans Yppighed, vi gyse ved Forestillingen om Nydelsessygens rædsomme Hevn, at hungre i Overflod; men det, at vi forgjeves søge den mindste Yttring af Kjerlighed, bestemmer os, idet vi sige, det er lidet opbyggeligt. - Naar vi see en talrig Familie indkneben i en lille Leilighed, og vi dog see den beboe en hyggelig, venlig, - rummelig Leilighed, saa sige vi, det er et opbyggeligt Syn, fordi vi see den Kjerlighed, der maa være i de Enkelte og i hver Enkelt, da jo een Ukjerlig allerede var nok til at tage hele Pladsen, vi sige det, fordi vi see, at der virkelig bliver Rum, hvor der er Hjerterum. Og derimod er det saa lidet opbyggeligt at see en urolig Aand beboe Palladset uden at finde Hvile i een eneste af de mange Sale, og uden dog at kunne afsee eller undvære det mindste Aflukke. - Ja, hvad kan ikke saaledes være opbyggeligt! At see et Menneske sove skulde man ikke troe kunde være opbyggeligt. Og dog, dersom Du seer Barnet sove ved Moderens Bryst - og Du seer Moderens Kjerlighed, seer, at hun ligesom har ventet paa og nu benytter Øieblikket, medens Barnet sover, til ret at glæde sig ved det, fordi hun neppe tør lade Barnet mærke, hvor usigeligt hun elsker det: saa er det et opbyggeligt Syn. Er Moderens Kjerlighed ikke synlig, søger Du forgjeves i hendes Aasyn og Mine at opdage det mindste Udtryk af Moderkjerlighedens Glæde over eller Omsorg for Barnet, seer Du kun Dorskhed, Ligegyldighed, som er glad ved saa længe at være Barnet qvit: saa er Synet heller ikke opbyggeligt. At see Barnet alene sove er et venligt, et velgjørende, et beroligende Syn, men det er ikke opbyggeligt. Vil Du alligevel kalde det opbyggeligt, saa 
I citatet ovenfor er det netop tydeligt, at vi ikke ser kærligheden, men det vi ser, gør noget ved os: Vi lader os opbygge. Beskrivelsen af det opbyggelige bygger på den umiddelbare oplevelse, vi har, når vi betragter husmoderen i billedet ovenfor. George Pattison betoner netop, at disse beskrivelser af det opbyggelige er så dagligdags, "hyggelige" og erfaringstætte, for at vise, at det er muligt for enhver, uanset religiøs overbevisning, at elske opbyggeligt. Men man kunne også sige, at det erfaringstætte i beskrivelsen netop skyldes, at når det gælder kærlighedens opbyggelighed, genkender vi denne umiddelbart i opfattelsen af kærligheden som en gave. ${ }^{14}$ Kierkegaards direkte henvendelse til læseren synes at bekræfte en sådan tolkning:

Har Du ikke selv erfaret dette m. T.? Dersom nogensinde noget Menneske har talt saaledes til Dig eller handlet saaledes mod Dig, at Du ret følte Dig opbygget derved, da var det fordi, Du ret levende fornam, hvorledes han forudsatte Kjerligheden at være i Dig (SKS 9, 225).

Gennem sin beskrivelse af det opbyggelige fremhæver Kierkegaard således, at kærligheden er en dynamisk egenskab ved mennesket, der ytrer sig gennem et særegent gaveforhold. Kærlighedens opbyggelige karakter bevirker, at det ene menneske flettes sammen med det andet på en sådan måde, at det bliver klart, at det ene menneske har indflydelse på det andet menneskes selvforhold.

Men hvad er nu Kjerlighed? Kjerlighed er at forudsætte Kjerlighed; at have Kjerlighed er at forudsætte Kjerlighed hos Andre, at være kjerlig er at forudsætte, at Andre ere kjerlige. Lad os forstaae hinanden. De Egenskaber, et Menneske kan have, maae enten være Egenskaber han har for sig, selv om han gjør Brug af dem mod Andre, eller Egenskaber for Andre. [...]Dersom derimod En vilde mene, at han var kjerlig, men tillige, at alle Andre ikke vare kjerlige, saa vilde vi sige: nei stop, her er en Modsigelse i selve Tanken; thi at være kjerlig er jo just at antage, at

er det fordi Du dog alligevel seer Kjerligheden tilstede, saa er det fordi Du seer Guds Kjerlighed omsvæve Barnet. - At see den store Kunstner fuldende sit Mesterværk, det er et herligt, et opløftende Syn, men det er ikke opbyggeligt. Sæt, dette Mesterstykke var et Underværk - hvis nu Kunstneren af Kjerlighed til et Menneske slog det i Stykker: saa vilde dette Syn være opbyggeligt. Overalt, hvor det Opbyggelige er, er Kjerlighed, og overalt, hvor Kjerlighed er, er det Opbyggelige" (SKS 9, 216f). 14. "Kierkegaard illustrates the point by taking as an example of how love is upbuilding a large family having to share a cramped apartment but who, nevertheless, live together in a loving way. In describing the kind of love such family exemplifies, he uses the term hyggelig, a term that might be translated as 'homely' or 'cosy' or, even perhaps, 'comfy', i.e. a term that emphasises the very ordinary, everyday humanness of the situation [...] Nothing could emphasise more strongly that the possibility of living out the meaning and value of love, and therefore of living as one require any particular dogmatic presuppositions", George Pattison, Kierkegaard's Upbuilding Discourses (London \& New York: Routledge 2002), 212. 
forudsætte, at andre Mennesker ere kjerlige. Kjerlighed er ikke en forsigværende Egenskab, men en Egenskab, ved hvilken eller i hvilken Du er for Andre (SKS 9, 225).

Som en egenskab ved kærligheden $i$ Grunden borger det opbyggelige for, at det ene menneske formår at forholde sig sådan til et andet menneske, at det kan have indflydelse på dets selvforhold. Kierkegaard siger, at kærlighed opbygger ved at forudsætte kærlighed. Hvad betyder det? Når det ene menneske forudsætter, at kærligheden er $i$ Grunden i det andet menneske, så opbygger det. Hvis det ene menneske omvendt ved sin måde at forholde sig til det andet menneske på indikerer, at den anden skulle mangle kærlighed, så "nedriver" det.

For at kunne tale om gavens, kærlighedens, opbyggelighed må der være én der elsker og én der elskes. En giver og en modtager. Gaven er ikke noget i sig selv. I den forstand er kærligheden et mellemværende; et mellemværende mellem de elskende. Kierkegaard siger derfor, som allerede nævnt, at kærligheden ikke er en for-sig-værende egenskab $i$ et menneske, men en egenskab, $i$ hvilken man er til for andre (se ovf.). Det betyder, at kærligheden former selvet socialt. Kierkegaard taler i den forbindelse om kærligheden, som den 3. instans i et forhold mellem elskende. "Først er der den Kjerlige; dernæst den eller De, som ere Gjenstanden; men for det Tredje er ogsaa Kjerligheden selv med tilstede" (SKS 9, 299). ${ }^{15}$ Først i dette mellemværende virkeliggøres kærlighedens gave. Det er den kærlighed, der allerede er givet $i$ Grunden, der virkeliggøres i forholdet mellem de elskende og udgør det mellemværende, de har, med hinanden. ${ }^{16}$

Nedenfor skal vi se nærmere på, hvorledes Kierkegaard forbinder dette mellemværende med en særlig form for gaveøkonomi, der kan

15. Andetsteds siger Kierkegaard siger, at kærligheden har 2 retninger, men 3 involverede parter og derfor udgør et trepartsforhold: "Idet nemlig Tvende i Kjerlighed forholde sig til hinanden, forholder hver især af dem sig i sig selv til "Kjerligheden" [...] Hvis Kjerlighed ene og alene var et Forhold mellem To, saa var jo den Ene bestandigt i den Andens Vold, forsaavidt denne Anden var en Nedrig, der ville bryde Forholdet. Naar et Forhold kun er mellem To, saa er den Ene bestandigt Forholdet overmægtig ved at kunne bryde det, thi saasnart den Ene har brudt, saa er Forholdet brudt" (SKS 9, 302).

16. Vi er således enige med Claudia Welz, når hun betoner følgende: "God's love is a spiritual reality 'between' the persons who act - a reality that is not just transcendent and 'beyond' them, but qualifies the situation in which they act. As such, however, it does neither appear as another loving subject next to the lover and the beloved, nor as an object they could give or receive; rather, it 'acts' or works as the medium by which one person loves another person", Love's Transcendence and the Problem of Theodicy (Tübingen: Mohr Siebeck 2008), 116. 
gøre sig gældende i alle kærlighedens skikkelser, hvorfor der bliver tale om et "Vexel-Forhold" mellem den, der elsker og den, der elskes. ${ }^{17}$

\section{Gavens karakter}

Når den ene giver den anden en gave, der kan gøres op i penge, så mister den, der giver, det han eller hun bortgiver. Således er det ikke med kærlighedens gave. Det er en gave, der kun kan gives, ved selv at beholde den og således forblive i kærlighedens gæld til den anden, den elskede. Derfor handler det ikke om, hvor meget man giver - det er jo netop afgørende, når man giver en gave, hvis kvantitet kan måles, som $\mathrm{fx}$ en pengegave - derimod handler det om, hvorledes man giver.

Kærlighedens opbyggelige hvorledes er netop at skænke sin kærlighed på en sådan måde, at man, idet man giver kærligheden som gave, forudsætter at kærligheden allerede er til stede i den elskede. I enhver lykkelig forkærlighedsforbindelse, hvor man elsker en eller ganske få frem for andre, som i elskovs- eller venskabskærligheden, vil denne forudsætning blive til genkærlighed, når den elskede returnerer den samme art kærlighed, som den, den elskende giver. I en ulykkelig forkærlighedsforbindelse vil genkærligheden udeblive. Men i både den lykkelige og den ulykkelige forkærlighedsforbindelse - og i næstekærligheden som aldrig er hverken lykkelig eller ulykkelig, fordi den ingen genkærlighed forudsætter - vil der opstå en ændring i modtageren, fordi hun fornemmer sig elsket og herved bliver sig sin elskværdighed bevidst.

Kierkegaard understreger igen og igen, at det ene menneske ikke kan skabe kærligheden i det andet menneske. Som vi har hørt er det "Gud, Skaberen, som maa nedlægge Kjerlighed i ethvert Menneske, han, der selv er Kjerlighed” (SKS 9, 219). Kierkegaard forbliver således inden for bygningsmetaforerne og siger, at kærligheden er " $i$ Grunden" i ethvert menneske. Kærligheden er en del af menneskets "fundament", og når det ene menneske giver det andet menneske sin kærlighed, så sker dette netop ved at forudsætte, at kærligheden allerede er i grunden i dette andet menneske og ud fra denne forudsætning fremelskes kærligheden: "Saaledes lokker han det Gode frem, han opelsker Kjerligheden, han opbygger. Thi Kjerlighed kan og vil kun behandles paa én Maade, ved at elskes frem; at elske den frem er at opbygge. Men at elske den frem er jo netop at forudsætte at den er tilstede i Grunden" (SKS 9, 220). Herved bliver den anden, den

17. M. Jamie Ferreira diskuterer gaveaspektet i kapitlet 'Love's Gift', i Love's Grateful Striving: A Commentary on Kierkegaard's Works of Love (Oxford: Oxford University Press 2001), 151-186. 
elskede, modtageren, sig bevidst om sin kærlighed og sin elskværdighed. Det at give kærlighed er altså ikke at skabe karlighed i den anden. Men det at give kærlighed er at tildele den anden elskverdighed på baggrund af forudsætningen om, at kærligheden allerede er i grunden i den anden.

Kærlighedens gave er således den andens bevidsthed om at være elskværdig. Hermed lægges ikke nødvendigvis op til en gengave, om end det i de lykkelige forkærligheds forhold vil være tilfældet, men er forholdet ikke et forkærlighedsforhold, men et næstekærlighedsforhold vil denne erhvervede bevidsthed om sig selv som værende elskværdig netop åbne forholdet op mod resten af verden og således åbne mulighed for at tale om gensidighed i den forstand, at der finder en ændring sted på begge sider af forholdet; både i giveren og i modtageren, hvorved modtageren lader sin nyvundne bevidsthed om sig selv som værende elskværdig komme andre end giveren til gode. ${ }^{18}$

Kærlighedens særegenhed som gave betragtet skyldes altså dens opbyggelighed. Om end kærligheden ikke besidder en egentlig bytteværdi, hvorfor modtagerens genkærlighed, aldrig kan antage karakter af gengald, så initierer den alligevel grundet sin opbyggelige karakter en gensidighed. Hvis modtageren elsker igen er det ikke for at returnere gaven, den elskedes kærlighed, med en tilsvarende gave. Der er derimod tale om at modtageren gennem giverens kærlighed lære kærligheden i sig selv at kende og således genkender den elskedes kærlighed. Modtagerens kærlighed må derfor ikke forstås som en gengave. Der er ikke tale om afdrag på en gæld, men som gensidig anerkendelse, eller måske rettere gensidig genkendelse: "Det sidste, det saligste, det ubetinget overbevisende Kjende paa Kjerlighed bliver derfor: Kjerligheden selv, der bliver kjendt og gjenkjendt af Kjerligheden i en Anden" (SKS 9, 24).

At kærlighedsforholdet kan beskrives som en uendelig gæld på giverens sides skyldes, at Kierkegaard opfatter kærligheden som en ganske

18. En sådan udvidelse af gensidighedstanken svarer ikke overraskende til det "flow of grace", som Niels Henrik Gregersen argumenterer overbevisende for, når han fx skriver: "I argue that interhuman generosity eventually is effective in interhuman communication. Generosity is only impossible if one portrays human society in such a manner that divisions, oppositions, and conflicts are unavoidable [...] By contrast, if human beings and their communities are thought of as concordant fellowships, then generosity and the circularity of benefits are to be expected as part of the elementary forms of human coexistence" (Gregersen (2009), 121). Niels Henrik Gregersen binder netop tanken om "the flow of grace" sammen med kærligheden som en særegen form for gave. Han skriver: "Likewise, giving love does not mean giving away, in the sense that love is lost: rather love can only exist by being exercised. The radical character of love's generosity thereby opens up for an investigation into how the concept of generosity can illuminate the corresponding theological concept of divine grace" (ibid.), 122f.). 
særegen gave. Kærlighed er en uendelig størrelse, der derfor ikke kan måles med en endelig målestok, som fx penge, ære eller løfter. Som en uendelig størrelse er det eneste mål hvormed man kan måle kærligheden netop dens uendelighed. Når det gælder kærlighed mellem to endelige størrelser, to mennesker, kan kærlighedens uendelighed kun måles på dens vedvaren i tid; den elskendes, giverens, vedvarende opofrelse for den andens skyld. ${ }^{19}$

Det synes altså at være gavens, kærlighedens, karakter af uendelig, der er bestemmende for den særegne økonomi i kærlighedsforholdet. En økonomi, der som nævnt får giveren, den elskende til at forblive i en ubetalelig og dermed uendelig gæld til den elskede:

Men dette er det Uendeliges Forhold, og Kjerlighed er uendelig. Ved at give Penge kommer man sandeligen ikke i Gjeld, tvertimod kommer jo Modtageren i Gjeld. Naar derimod den Elskende giver, hvad der uendeligt er det Høieste, det ene Menneske kan give det andet, sin Kjerlighed, saa kommer han selv i en uendelig Gjeld. Hvilken skjøn, hvilken hellig Undseelse fører ikke Kjerligheden med sig; den ikke blot ikke tør overtale sig til at blive sig sin Gjerning bevidst som noget fortjenstligt, men den undseer sig endog for at blive sig sin Gjerning bevidst som et Afdrag paa Gjelden; den bliver sig sin Given bevidst som en uendelig Gjeld, hvilken det jo er umuligt at afbetale, da bestandigt det at give er at komme i Gjelden (SKS 9, 176).

Som nævnt er det ikke enhver gave, der kan gives på en sådan måde, at det er modtageren der kommer i gæld. Kærligheden besidder denne egenskab fordi den er uendelig, men hvad vil det egentlig sige?

19. " Lad os begynde med et lille Tanke-Forsøg. Dersom en Elskende havde gjort for den Elskede noget, menneskeligt talt, saa Overordentligt, saa Høimodigt, saa Opoffrende, at vi Mennesker maatte sige "dette er det Høieste, det ene Menneske kan gjøre for det Andet": saa var dette jo smukt og godt. Men sæt han tilføiede "see nu har jeg betalt min Gjeld": var dette da ikke ukjerligt, koldt og strengt talt, var det ikke, om jeg saa tør sige, en Uanstændighed, som aldrig burde høres og heller aldrig høres i den sande Kjerligheds gode Selskab! Dersom derimod den Elskende havde gjort dette Høimodige og Opoffrende, og nu tilføiede "dog har jeg een Bøn, o, lad mig forblive i Gjelden": var dette ikke kjerligt talt! Eller hvis den Elskende med enhver Opoffrelse føier den Elskedes Ønske og nu siger "det er mig en Glæde med Dette at afdrage en Smule paa den Gjeld - i hvilken jeg dog netop ønsker at blive": var dette ikke kjerligt talt! Eller hvis han reent fortiede, at det kostede ham Opoffrelse, blot for at undgaae det Forvirrende, at det et Øieblik kunde synes som et Afdrag paa Gjelden; var dette ikke kjerligt tænkt! Naar saa er, er det jo udtrykt, at et egentligt Regnskabs-Forhold er utænkeligt, er Kjerligheden det Vederstyggeligste. Et Regnskab kan kun finde Sted, hvor der er et endeligt Forhold, fordi det Endeliges Forhold til det Endelige lader sig udregne. Men den Kjerlige kan ikke regne. Naar den venstre Haand aldrig faaer at vide, hvad den høire gjør, saa er det umuligt at gjøre et Regnskab op, og ligesaa naar Gjelden er uendelig. At regne med en uendelig Størrelse er umuligt, thi at regne er netop at endeliggjøre” (SKS 9, 178). 
Kierkegaard forklarer, at "Kjerlighedens Element er Uendelighed, Uudtømmelighed, Umaalelighed" (SKS 9, 180). Element benyttes her i betydningen livsbetingelse, på samme måde som fiskens element kan siges at være vandet. Når der tales om livsbetingelser i forbindelse med kærligheden må det betyde, at disse må være til stede eller tilvejebringes for at kærligheden kan leve. At skænke sin kærlighed på en sådan måde at disse livsbetingelser fremmes, er at give kærlighedens gave til den elskede.

Det modsatte af uendelighed er endelighed og dermed den endelighedens målestok, som vi benytter når vi fx giver penge, ære eller løfter ud. Det modsatte af uudtømmelighed er det at kunne løbe tør for kærlighed, det at kunne elske nok. Det modsatte at umålelighed er det at kunne måle eller rettere sammenligne sin kærlighed med kærligheden i den anden eller bare med andres kærlighed. Alle disse tre livsbetingelser; uendeligheden, uudtømmeligheden og umåleligheden peger således i retning af at kærligheden som en grundlæggende overflod i ethvert menneske, der aldrig løber tør og aldrig kan inddæmmes af sammenligningen med kærligheden i andre. Som ovenfor anført kan det ene menneske kende og genkende sin kærlighed i det andet menneske, men det er langtfra det samme som at kunne sammenligne sin kærlighed med kærligheden $\mathrm{i}$ andre.

\section{Trangen til at give og til at modtage}

Beskrivelsen af kærligheden som en trang, som vi finder gentagne gange i Kjerligheden Gjerninger, synes primært at bygge på Sokrates' gengivelse af Diotimas mytologiske beskrivelse af guden Eros i Platons Symposion. Diotima præsenterer Eros som et elskovsbarn af den dristige og skønhedssøgende Poros og den fattige og hjemløse Penia. Eros er derfor et dobbeltvæsen i den forstand, at han står midt imellem visdom og uforstand, mellem fylde og tomhed, mellem rigdom og fattigdom, og derfor er han konstant stræbende. I Kjerlighedens Gjerninger henviser Kierkegaard direkte og med tilslutning til Diotimas mytologiske beskrivelse af guden Eros' dobbelttydige ophav:

Paa forskjellige Maader har man søgt at betegne og beskrive, hvorledes Kjerligheden fornemmes af Den, i hvem den er, Tilstanden i Kjerlighed, eller hvorledes det er at elske. Man kalder Kjerligheden en Følelse, en Stemning, et Liv, en Lidenskab; dog da dette er saa almindelig en Bestemmelse, har man nøiagtigere søgt at beskrive den. Man har kaldet den et Savn, men vel at mærke et saadant, at den Elskende bestandigt savner, hvad han dog besidder, en Længsel, men vel at mærke bestandigt efter det, som den Elskende dog eier - thi ellers er det jo ulykkelig 
Kjerlighed, man beskriver. - Hiin eenfoldige Vise i Oldtiden har sagt, at "Kjerlighed er en Søn af Rigdom og Armod" (SKS 9, 175).

Den dialektik, der ligger i Diotimas beskrivelse af Eros som søn af mangel og overflod, fattigdom og rigdom, afspejles i den måde, hvorpå Kierkegaard opfatter kærligheden som en grundlæggende dobbeltrettet trang i ethvert menneske; en trang til at elske og til blive elsket. Kierkegaard opfatter både kærligheden som en trang i betydningen en mangel; man trænger til noget, man ikke har, som når den tørstige trænger til vand. Men ordet trang kan også indikere et overskud eller en rigdom, noget man har for meget af; som når man trænger til at meddele sig; til at sige eller vise en anden sin glæde, sin sorg - eller sin kærlighed. ${ }^{20}$

For Kierkegaard er problemet med eroskærligheden derfor ikke, at længselsaspektet betones, men at det betones ensidigt. Og det er netop en sådan ensidig betoning, der gør sig gældende i Anders Nygren (1890-1978) nu navnkundige skelnen mellem den antikke eroskærlighed som et begærsbaseret forsøg på behovstilfredsstillelse, sat i forhold til den kristne kærlighedstanke, som Nygren benævner agape og opfatter som en "ren" kærlighed", der ikke gives for at få, men udelukkende udspringer af et overskud og rettes mod den anden og dennes ve og vel uden noget ønske om gensidighed. ${ }^{21}$ Det er således en opdeling af kærligheden som enten hvilende på en mangel eller på et overskud, der har ført til Nygrens skarpe skelnen mellem eros og agape. En skelnen, der stort set er tænkt med i enhver senere udformning af kærligheds tanken og udgør baggrunden for den skelnen mellem Need-Love og Gift-Love, som C.S. Lewis (1897-1963)gør sig til talsmand for i Four Loves. 22

Kierkegaard skelner derimod ikke mellem eros og agape eller mellem Need-Love og Gift-Love, men indoptager den dobbelthed, der ligger i Diotimas mytologiske beskrivelse af Eros' ophav, i sit dialektiske syn på kærligheden som en dobbeltrettet trang: En trang til at elske og en trang til at blive elsket. For Kierkegaard viser kærligheden sig både som en trang til at give kærlighed og således skænke en anden den kærlighed, der trænger sig på fra grunden af $\mathrm{i}$ ethvert menneske. Men samtidig er vi også drevet af en trang til at modtage kærlighed: En længsel efter at blive elsket af en anden og således modtage kærligheden udefra. For Kierkegaard udgør trangen til at elske

20. Vi mener således ikke, at der er helt så langt mellem "Diotima's ladder of erotic desire" og Kierkegaards Kjerlighedens Gjerninger, som Robert Perkins noget umotiveret antager i sin indledning til International Kierkegaard Commentary, Works of Love, red. Robert L. Perkins (Macon: Mercer University Press (1999), 1.

21. Anders Nygren, Den kristne karlighedstanke (København: Munksgaard 1965).

22. C.S. Lewis, The Four Loves (London: Harper Collins Publishers (1960) 2002). 
og blive elsket således to sider af den ene og samme kærlighed. Og det er sammentrækningen af disse to sider ved kærligheden, der danner baggrunden for dens særegne økonomi:

Man har kaldet den et Savn, men vel at mærke et saadant, at den Elskende bestandigt savner, hvad han dog besidder, en Længsel, men vel at mærke bestandigt efter det, som den Elskende dog eier - thi ellers er det jo ulykkelig Kjerlighed, man beskriver - Hiin eenfoldige Vise i Oldtiden har sagt, at "Kjerlighed er en Søn af Rigdom og Armod" (SKS 9, 175).

Kierkegaard introducerer hermed tanken om en dialektisk forbindelse mellem længsels- og overflodsaspektet i kærligheden, når han beskriver denne som en i mennesket iboende trang. At mennesket har en trang til at elske kan både betyde, at det længes efter nogen at elske og altså mangler en modtager til sin kærlighed. Men det kan også betyde, at kærligheden trænger sig på i et menneske på en sådan måde, at kærligheden skænkes til den anden ud af en overflod, der aldrig løber tør, men presser sig på med gavens gavmilde generøsitet.

\section{Modtagerens tilegnelse}

Når Kierkegaard beskriver giveren af kærlighed som værende den, der står i gæld til modtageren, så ville det ligge lige for at beskrive modtageren som den, der skal inddrive gælden. Men det er vigtigt har at understrege, at dette ikke er Kierkegaards måde at tænke sig forholdet til modtageren på, når det drejer sig om at skænke kærlighedens gave.

Lad os for at belyse Kierkegaards syn på modtagerens rolle inddrage forordet til den lille samling af tre altergangstaler fra 1849, der bærer titlen "Yppersteprasten"- "Tolderen"- "Synderinden" og se på den tilegnelse til læseren, der i sin grundform er indoptaget i alle forordene til Kierkegaards samlinger af opbyggelige tale og således kan betragtes som paradigmatisk for Kierkegaards syn på sin læser som modtager af talerne. I det lille forord til de tre altergangstaler udbygges tilegnelsen til læseren på en sådan måde, at ingen kan være i tvivl om, at det handler om at give og i særdeleshed om at modtage:

Hiin Enkelte, hvem jeg med Glæde og Taknemlighed kalder "min Læser", modtage Gaven. Vistnok er det at give saligere end det at modtage; men er dette saa, er jo just den Givende i een Forstand den Trængende, trængende til den Salighed at give; og naar saa er, er jo Dens Velgjerning den største, Dens, der modtager - og saa er det jo dog saligere at modtage end at give (SKS 11,247). 
Kierkegaard knytter her til ved den tanke vi behandlede ovenfor, at det er den, der giver, der tranger til at give, jf. beskrivelsen overfor af kærligheden som en overflod i mennesket, et overskud der trænger sig på og rettes mod den anden. Men i dette forord lægger Kierkegaard mest vægten på modtageren og hendes rolle i gaves økonomi. Når det siges, at det er saligere at modtage end det er at give, så betyder dette selvfølgelig, at også modtageren har en aktiv part i gavegivningen. Modtageren skal nemlig gøre noget med gaven. Modtageren skal tilegne sig gaven på en sådan måde, at den bliver hans eller hendes ejendom. Men giver det nogen mening, når talen er om kærlighed? Kan det ene menneske gøre den kærlighed, det modtager fra et andet menneske, til sin kærlighed? Nej, det er naturligvis ikke muligt. Som vi allerede har været inde på udgør kærligheden en særegen gave, hvilket opstiller en særegen økonomi mellem giver og modtager.

Sådan som Kierkegaard ser det, så ejer hverken giveren eller modtageren den kærlighed den ene giver den anden. Det er derfor han i Kjerlighedens Gjerninger som nævnt betoner, at ethvert kærlighedsforhold består af tre parter:

Den blot menneskelige Opfattelse af Kjerlighed kan aldrig komme videre end til det Gjensidige: at den Elskende er den Elskede og den Elskede den Elskende. Christendommen lærer, at en saadan Kjerlighed endnu ikke har fundet sin rette Gjenstand: Gud. Der hører til et Kjerligheds-Forhold det Tredobbelte: den Elskende, den Elskede, Kjerligheden, men Kjerligheden er Gud. Og derfor er det at elske et andet Menneske at hjælpe ham til at elske Gud, og det at være elsket det at blive hjulpen $(S K S$ 9, 124).

Kierkegaard introducerer således et særegent forhold mellem den, der giver kærlighed og den der modtager kærlighed. Det særegne ved forholdet beror på, at kærligheden er en særlig gave, der kun kan gives på en sådan måde, at den, der skænker en anden sin kærlighed samtidig beholder den. Og den der modtager denne gave, blot får, hvad hun allerede har, kærligheden i grunden, men nu skal tilegne sig denne kærlighed, som givet at en anden. Denne tilegnelse kan finde sted på to måder afhængig af, om der er tale om kærlighed til en særligt elsket, elskovs- eller venskabskærligheden. Eller om kærlighed til næsten.

Tilegnelsen af elskovs- og venskabskærlighed kan enten bestå i genkærlighed (i de lykkelige forhold) eller afvisning af modtagelsen (i de ulykkelige forhold). Når det gælder næstekærligheden er dét næsten modtager, en bevidsthed om sin egen elskværdighed. Modtagerens, næstens, tilegnelse består derfor i, at den skænkede kærlighed får betydning for hendes forhold til sig selv og hendes forhold til ethvert andet menneske. Når det gælder næstekærligheden gør der sig således et særegent vekselforhold gældende mellem den, der elsker og den, der elskes. Der er tale om en form for vekselforhold, der ikke hviler på en absolut gensidighed og derfor hverken kan 
kaldes gengæld eller genkærlighed. Alligevel sker der noget på begge sider af forholdet. Både i den, der elsker, og i den, der elskes. Det skyldes kærlighedens opbyggelighed og dermed gavens karakter.

\section{Gavens gensidighed}

Hvad er det, der er ældre end Alt? Det er Kjerlighed. Hvad er det, der overlever Alt? Det er Kjerlighed. Hvad er det, der ikke kan tages, men selv tager Alt? Det er Kjerlighed. Hvad er det, der ikke kan gives, men selv giver Alt? Det er Kjerlighed [...] Hvad er det, der lægger Velsignelse i Gavens Overflod? Det er Kjerlighed. Hvad er det, der lægger Fynd i Engles Tale? Det er Kjerlighed. Hvad er det, der gjør Enkens Gave til Overflod? Det er Kjerlighed (SKS 5,65).

Citatet stammer fra den første af de Tre opbyggelige Taler 1843, "Kjerlighed skal skjule Synders Mangfoldighed". Her fokuseres på, hvorledes kærligheden ændrer forholdet mellem giver og modtager. Det særegne ved kærligheden i gaveøkonomiens optik er, at det at skænke kærlighed, at give den som en gave, jo ikke betyder, at giveren selv mister den kærlighed han eller hun giver bort. Man kan således give en anden sin kærlighed uden selv at miste den. Men kan man så også regne med at få kærlighed igen, hvilket vil være konsekvensen af at læse den ovennævnte gaveøkonomi ind i Kierkegaards syn på kærlighed i den nævnte passage? Man kan naturligvis ikke regne med, at ens kærlighed bliver gengældt en til en og som sådan ville kunne indsættes i et regnestykke af bytteværdi. Men man kan faktisk godt regne med, at den kærlighed man skænker, bliver modtaget og som sådan indoptaget af den anden og således ændrer hans eller hendes selvforstålse og derfor igen hans eller hendes forhold til andre. Det er det særegne ved kærligheden. Den indfører en økonomi, der er helt anderledes end retfærdighedens økonomi. Kærlighedens økonomi er netop gavens, der ikke hviler på et bytteforhold, men på en gensidig udveksling af anerkendelse og respekt på baggrund af kærligheden som fælles værdi. Kærlighedens økonomi er således en særegen variation af gavens økonomi.

Det er kærligheden, der gør, at det at give er saligere end det at modtage samtidig med, at det der modtages, fornemmes større end det, der rent faktisk gives: "Hvo modtog vel ogsaa Mere end Den, der modtog et Menneskes Kjerlighed; og hvo gav Mere end den, der gav et Menneske sin Kjerlighed" (SKS 9, 176), som det lyder i Kjerlighedens Gjerninger. 
Denne særegne variation eller måske direkte korrektion af gaveaspektet kommer tillige frem i de ovenfor citerede udsagn om, at kærligheden ikke kan tages, men selv tager alt, samt at den ikke kan gives, men selv giver alt. Korrektionen består for det første i, at Kierkegaard i den citerede passage lægger op til at forstå kærligheden som en magt, der indoptager både givers og modtagers rolle og som sådan evner at sætter sig igennem på nærmest suveræn vis. For det andet bliver opfattelsen af selve kærligheden som en gave, den ene kan give den anden, afvist, idet det betones, at kærlighedens magt består $\mathrm{i}$ at kunne give sig selv. Kærligheden korrigerer gavens økonomi, fordi den både repræsenterer en given og modtagen og således skabes et særegent vekselforhold:

Men det at være og forblive i en uendelig Gjeld, det er netop et Udtryk
for Kjerlighedens Uendelighed, saa den ved at blive i Gjelden bliver i sit
Element. Der er her et Vexel-Forhold, men uendeligt fra begge Sider. I
det ene Tilfælde er det den Elskede, der i hver en Yttring af den Elsken-
des Kjerlighed kjerligt fatter Umaaleligheden; i det andet Tilfælde er
det den Elskende, der føler Umaaleligheden, fordi han erkjender Gjel-
den at være uendelig: det er Eet og det Samme, der er uendeligt stort
og uendeligt lille. Kjerlighedens Gjenstand tilstaaer i Kjerlighed, at den
Elskende ved det Mindste gjør uendeligt mere end alle Andre ved alle
de største Opoffrelser; og den Elskende tilstaaer sig selv, at han ved alle
mulige Opoffrelser gjør uendeligt mindre, end han fornemmer Gjelden
at være. Hvilket vidunderligt Lige for Lige i dette Uendelige! (SKS 9,
181).

Det syn på kærligheden, der gør sig gældende i en række af Kierkegaards opbyggelige taler samt i Kjerlighedens Gjerninger, viser sig således at indeholde en særegen opfattelse af gavens økonomi. Forholdet mellem giveren, den elskende, gaven, kærligheden, og modtageren, den elskede, kan beskrives som et særligt gensidighedsforhold, der på mange måder svarer til den gaveøkonomi Mauss afdækkede gennem sine antropologiske studier og som Derrida, Lévinas og Marion videreudvikler og problematiserer. Kierkegaards beskrivelse af kærligheden som en særegen gave magter at indoptage det gensidighedsaspekt, der ligger implicit i talen om gavens økonomi på en måde, der tillader ham at pege på, at der både finder en ændring sted i den, der giver og i den, der modtager kærlighed. Denne ændring består i et særegent vekselforhold, der aldrig kan udmønte sig i et krav om gengæld eller genkærlighed, men alligevel må opfattes som et gensidighedsforhold mellem giver og modtager, hvorved Kierkegaard faktisk forgriber flere af de indsigter, som de nye teologiske læsninger af gavens økonomi, der er repræsenteret i denne artikel, afspejler. 